\title{
ECHOES OF WAR 1915-1918 (Part 4)
}

\section{C.G.J. Lawrenc}

During the summer months of 1917-1918 there was a strange quiet on the Eastern front. The downfall of Russia afforded General E. Ludendorff, who became the first quartermaster general of the German armies when Field Marshal von Hindenburg assumed the office of chief of the German general staff of the armies in the field, the opportunity to deal the Allies in the west a decisive blow. Instead he decided to work to perfect his preparations for his final coup. His plan was based on the highly specialized training of certain units, and was a legitimate conclusion from the German use of 'storm troops'. The first point was the absence of any preliminary massing near the front of attack. Men were brought up by night marches just before zero hour, and secrecy was thus obtained for the assembly. Again, there was no long bombardment to alarm the enemy, and the guns began at the moment when the infantry advanced, the enemy's back areas being confused by a deluge of gas shells. The assault was made by picked troops in open order, or rather in small clusters, carrying light trench mortars and many machine guns, with the field batteries close behind them in support. The actual mode of attack, which the French called 'infiltration', may be likened to a hand, of which the fingertips are shod with steel, and which is pushed into a soft substance. The picked troops at the finger-ends made gaps through which others poured, till each section of the defence found itself outflanked and encircled. A system of flares and rockets enabled the following troops to learn where the picked troops had made the breach, and the artillery came close behind the infantry. The men had unlimited objectives, and carried iron rations for several days. When one division had reached the end of its strength, another took its place, so that the advance resembled a continuous game of leap-frog.

This method was the opposite of the old German mass attack, which had seen a succession of hammerblows on one section of the front. It was strictly the filtering of a great army into a hostile position, so that each part was turned, and the whole front was first dislocated and then crumbled. His scheme demanded individual stamina and high perfection and to enable his troops to succeed, the whole of the Eastern Front was turned into one vast training camp which lead to a lull on the Western Front.

\begin{abstract}
During this period Second Lieutenant G.G.J. Lawrence was granted a spell of leave which he spent in London. On his retum he was posted to $A$ Company nucleus before marching to the front with the Brigade. On 12 March 1918 the Brigade relieved the 29th Division to form forthwith the extreme left of the Fifth Amy, with the 21st Division on its right and the 47th (London Territorial) Division on its left.
\end{abstract}

About this time our air force spotted large concentrations of enemy troops well behind the lines opposite the area of the 3rd and 5th Armies and we were alerted to counter a heavy attack in the forthcoming battle. Two dates were given, the 19 th and the 21st March. For the first time we heard that the enemy had tanks and would very likely use them against us. Junior officers were asked for their ideas of how to deal with them - quite a poser. There was a tense feeling amongst all ranks as the days drew nearer to the 19th. There was an unusual and ominous quiet and practically no shell fire. Tuesday the 19th came and went with no signs from the enemy; a drizzle fell all day but cleared the next day. We now knew it must be the 21 st and that we would be handicapped by a heavy fog that had rolled down on us. One could not see more than a few yards. And so the 20th was spent just waiting for the storm to burst. That night the officers of our details ${ }^{1}$ slept uneasily in a Nissen hut in the reserve line.

The next morning at a quarter-to-five the German barrage came down with a thunderous crash from thousands of guns of all sizes (the heaviest bombardment known on the Western Front). We lit our candles and burrowed as close as we could get to the ground. First a shell blew one door in and then the other near me. The candles went out and we groped for our gas helmets in the dark. Splinters of metal were making sparks as they fell through just above us and the din was quite indescribable. Soon amongst the high explosive shells falling all around we heard the unmistakeable plop, plop, as gas shells fell mixed with the others and the burnt potato or onion smell warned us it was time to put on our gas helmets.

1. The remaining officers, N.D.O.'s and men, about 300 strong formed a reserve known as the details and henceforth fought as a separate unit. They were posted to battle positions in the reserve line. 
One poor chap could not find his helmet, another had his torn across his face by a flying piece of shrapnel. We waited apprehensively for a direct hit any moment but luckily none came and the barrage lifted back to the front line and also to the artillery lines. We then all staggered out to find our battle positions, trying as best we could to see through helmet eye pieces and the dense fog.

We were making very slow progress when Sergeant-Major Alex Smith did a very brave thing by pulling off his gas helmet fully aware of the grave risk, and led us through the thick gas to our allotted posts. I was quite aghast at Smith's selfless act deliberately inviting a cruel death... death we had witnessed so graphically in our reserve line the terrible sight of gassed men caught by the mixed gas and high explosive shell fire, probably newcomers. They were carried past on stretchers in what seemed an endless procession, each man in extremis frothing at the mouth and blowing bubbles. A frightful and unnerving sight seen by us all.

Our men in the front line were holding firm in spite of heavy shelling followed by attacks from the enemy infantry. As the morning wore on the enemy broke through on the right flank ${ }^{2}$ of our Brigade but our men held on until they were surrounded and had to fight their way back to the reserve line early on the morning of the 22nd. We, the details, were ordered to fall back and take up positions in the Green Line in support of our front line troops. ${ }^{3}$

2. During the first rush of the attack on 21 March, the Germans forced the left brigade of 21 Division back to enable them to take up a cluster of mined buildings called Vaucellette Farm. This they used as an assembly position for extending their attacks. The right flank of the Fourth African Brigade at Gauche Wood was therefore wholly exposed.

3. The reason for this order lay in the general position of the battle. On the Fifth Army front the Germans had before midday broken into our battle zone at Ronssoy, Hargicourt, Templeux, and Le Verguier, and were threatening the valley of the Omignon. Later came news that the same thing had happened at Essigny and Maissemy. In the Third Army area the forward zone had gone at Lagnicourt and Bullecourt, and the fight was being waged in the battle zone northward from Doignies to the Sensée. Against 19 British divisions in line Ludendorff had hurled 37 divisions as the first wave, and before the dark fell not less than 64 German divisions had taken part in the battle - a number much exceeding the total strength of the British Army in France. In such a situation the Flesquières salient could not be maintained, though it had not been seriously attacked, and Byng's withdrawal from it meant a corresponding retirement by the 9th Division, which, except for Gauche Wood, had yielded nothing.

Accordingly during the evening and early night the South African Brigade fell back from the whole forward zone to the Yellow Line, the reserve position of the battle zone. The general line of the railway east of Gouzeaucourt was held up till 2 a.m. on the $22 \mathrm{nd}$, and by 5 a.m. the retirement was complete.

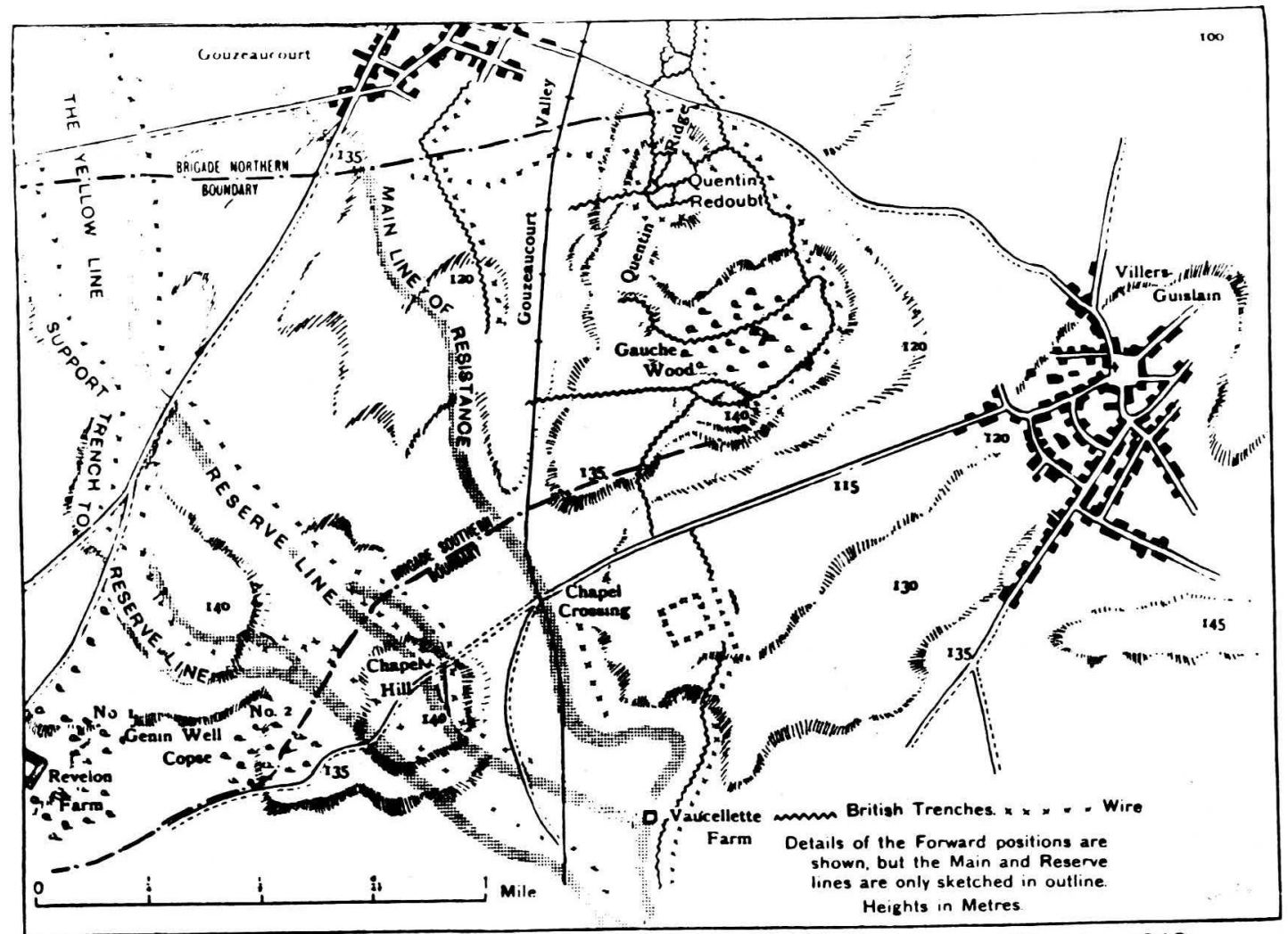

Positions held by the South African Brigade at the outset of the German Offensive 1918. 
Making our way back through the dense fog, Sergeant-Major Alex Smith, with his pistol in hand saw someone in the fog in front of him going the same way as ourselves, holding an open map with both hands and marching calmly on. To his surprise when the fog lifted a little he saw it was a German officer. He had no option but to step forward a few paces and finish him with a bullet in his back. On reaching our battle post in the Green Line on the Fins-Nurlu road we got moving to improve our trench and siting our machine and Lewis guns. We hunted around for extra ammunition and were able to pile up a goodly supply for all arms.

At one time I was looking into the dense fog in front of us when I saw what looked like a pole and which I had not seen there before. I grabbed a rifle, aimed carefully and fired but nothing happened; the pole remained. I looked at my sights and found they were set at $600 \mathrm{yds}$. I put them down to zero, fired again and the Jerry went down like a stone. Without doubt it was no pole.

During the early morning of the 22/23rd the 1 st Regiment with Colonel Heal bringing up the rear passed through our lines to take up positions at Marriers Wood behind us. The whole column of dazed and utterly weary men halted for a few minutes. I went to the rear to see Colonel Heal. He told me how his men had fought the enemy to a standstill. When surrounded, due to the enemy break-through on the right, they had fought their way back. He was hoping they would have a few hours rest before being engaged again. He was so gentle, understanding and informal, almost as if he knew he would not survive the epic fight of the Brigade the following day. He wished me luck and said goodbye before ordering the column to move on. We now became the rear guard to the Brigade and part of the adjoining Division on our right.

Early on the morning of the 23rd Major Ormiston came up and gave the officers our orders. He said 'You are now the rear guard to the whole of this front and you are to hold this line. You will fight to the last man and the last round. There will be no surrender and no retreat. All forward troops of ours retiring, will be stopped on this line, if necessary, with your revolvers and you will shoot any man who refuses to stand".

When he left we set about further improving our defences and awaited the approached enemy. It is difficult to describe the feeling that came over me then that this was to be our final sacrifice. No heroics, but a feeling of great spiritual uplift. We few were safeguarding our weary Brigade - here we stand and here we die - a feeling of utter release from the cares of life and things material came over me. It is not possible to convey the uplift and supreme elation of those moments.

Shortly after midday we could see troops of our adjoining division streaming back on our extreme right and later nearer to us. Bursting shells falling everywhere, dumps of ammunition going up and

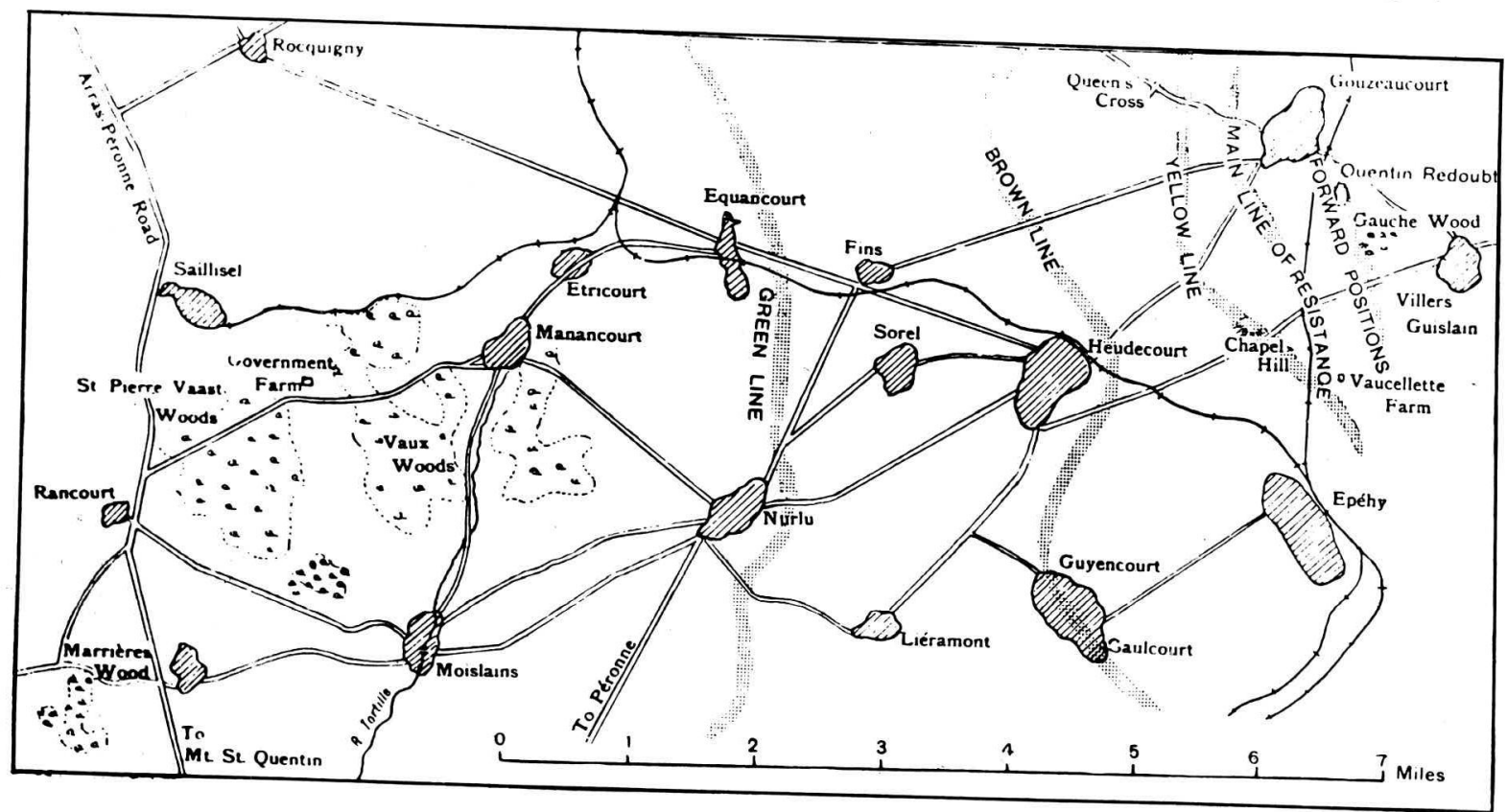

Retreat of the South African Brigade. 
burning food supplies emitting great clouds of black smoke. I saw a driverless horse harnessed between the shafts of a mess cart rushing at full speed back towards us and being followed by exploding shells from the enemy gunners. He swayed between the shell holes and somehow got back without upsetting the cart.

The enemy was following closely behind the retreating troops and were soon close to our line hoping to break through. We stopped many men of all Divisions with our revolvers in our hands but were never required to use them.

I stopped a young corporal of the Northumberland Fusiliers in charge of a Lewis gun team who spiritedly said at once that he was quite prepared to make a stand and only too pleased to be given definite orders by an officer. Between us we sited his gun to bear with infilading fire across our front. Just then a terrific racket broke out on our right with heavy enemy shelling and machine gun and rifle fire from our troops. I suggested to Captain Hallack that we go down to the trench to see what was happening. As we were making our way along a grenade was fired at us from the Jerries who had by this time reached our wire in front of us. The grenade exploded in the trench and Captain Hallack, close behind me, was severely wounded in the back and lungs. Stretcher bearers came forward at once and attended him. I ordered them to take four bearers and get back to Moislains as best as they could with Captain Hallack.

I went on down to the trouble area and found our men were holding well and doing a lot of execution amongst the attackers. The enemy was halted by our accurate fire and their infantry was clustering behind a series of square-shaped manure heaps left by the French peasant farmers. Our line formed a long inverted arc from the left of my position to where I now was. I could see that the enemy infantry, well protected by the manure dumps here on the right, were vulnerable to fire from our position on the left. I got back as fast as I could and told the Northumberland Fusilier and his team to follow me. We climbed out of our low trench and crept up to some Nissen huts divided by a sandbag wall. Peeping over, as I expected, I could see that I had a clear view of about ten of the enemy closely grouped behind their manure heap less than fifty yards distant. I said 'Give me the gun'. I let loose with a half drum of murderous fire into the bunch. There was only one survivor who staggered away in the mist to report back. I then raised my fire to the groups sheltering further down and was astonished to see the flashing flight of my bullets in a curving trajectory down on to my more distant targets.

The Lewis gunners had previously loaded their drums with one tracer round of ammunition to every five ordinary for anti-aircraft fire. This gave our position away very glaringly to the enemy artillery and they immediately opened up on us with bursts of shrapnel and high explosive shells. We moved fast and got back to our trench.

Things were getting very critical with the enemy in our wire nearby and once again in the distance the division to our right was moving back and leaving us all but surrounded. Major Ormiston came at this time and ordered me to get all my men away in sections to our reserve line at Moislains and to stay until the last with the final section for cover. I did this in relays, meanwhile having all remaining ranks giving rapid fire at anything or everything they could see to hide our very real weakness. I then got the last section of 10 men, told them to follow me in single file, and to follow me very closely. We hopped out of the trench with the Hun infantry in our wire firing wildly. I put on a sharp pace and led at right angles to our trench. The enemy by this time had got his field guns in our wire on a rise and started firing point blank over open sights at us. They were so close and apparently excited that their aim was poor. One shell flew just over our heads, the wind of it lifting our helmets, and burst in front of us. The next two ploughed a furrow at the side barely a few feet away bursting forwards. The close distance and high velocity apparently caused the bursting splinters to travel alongside and forward of us.

As soon as they had our range I took a sharp left incline to put off their aim. My squad followed closely. When I thought they had made their new correction I switched quickly to a right incline. I was right for their next shells burst where I had been. I repeated these tactics until our little squad reached a fold in the ground and out of sight of the gunners. I followed the low valley and was soon clear of artillery and rifle fire.

Soon after I caught up with our four stretcher bearers carrying Captain Hallack. As they were quite dead beat I changed the bearers and carried on with them. We passed an enormous shell hole, one a small house could fit in, and in it were a group of our wounded, all bad cases. One little fellow pleaded and begged not to be left. I could 
only say I was sure Jerry would tend to them. His pleading - 'Don't leave us, Sir', rang in my ears as we left them to their fate.

My job was to get my stretcher party back with as many fighting men as possible. In any case it was quite impossible to help them back. Soon I had to change bearers frequently. I sent my squad ahead to report to our next defence line and relied on getting new bearers from any retreating troops. None of these demurred but changed sharply when ordered in spite of the danger from the now advancing Germans. The enemy following up were close behind and firing as they came. At one stage a machine gun opened fire, fortunately wildly. We were too weary to do anything but just stand. Luckily one of our planes, seeing our plight, dived down and shot up our pursuers and soon quietened them. We again picked up the wounded man and moved on slowly in peace. We crossed a small running stream with difficulty, and moved up over a slight rise. Here at last we found the casualty clearing station we were looking for.

Handing over my casualty to the Colonel in charge I asked him to direct me to Bouchavesnes Ridge. He said, 'It is nearly sunset; you will not reach it tonight. You must stop here'. I said, 'I am sorry, Sir, I have orders to report to our Brigade Headquarters at Bouchavesnes Ridge'. I must have looked pretty gone in for he said, 'My orders are that you stay here tonight'. I had no option but to stay, much against my will. I was fortunate, for being very keen to rejoin my regiment I would very probably have reached them that night only to be surrounded and cut off the next day when the Brigade made their famous stand and fought to a finish.

The 500 men under General Dawson fought to the last round of ammunition. Less than 100 men, some of them wounded, were left to surrender. The casualties were terribly high. Amongst those killed were my commanding officer, Colonel Heal, DSO, Major Cochran and all too many of my old comrades. For seven hours from early morning the Brigade, hopelessly outflanked on both sides, fought off the enemy. Brigadier General Dawson had orders to hold his position at all costs and by doing so probably saved the 5th Army and the whole British front.

When his men trudged back to the prison camps they saw roads blocked with artillery and transport. The enemy's whole move forward had been stopped in its tracks for those vital seven hours of

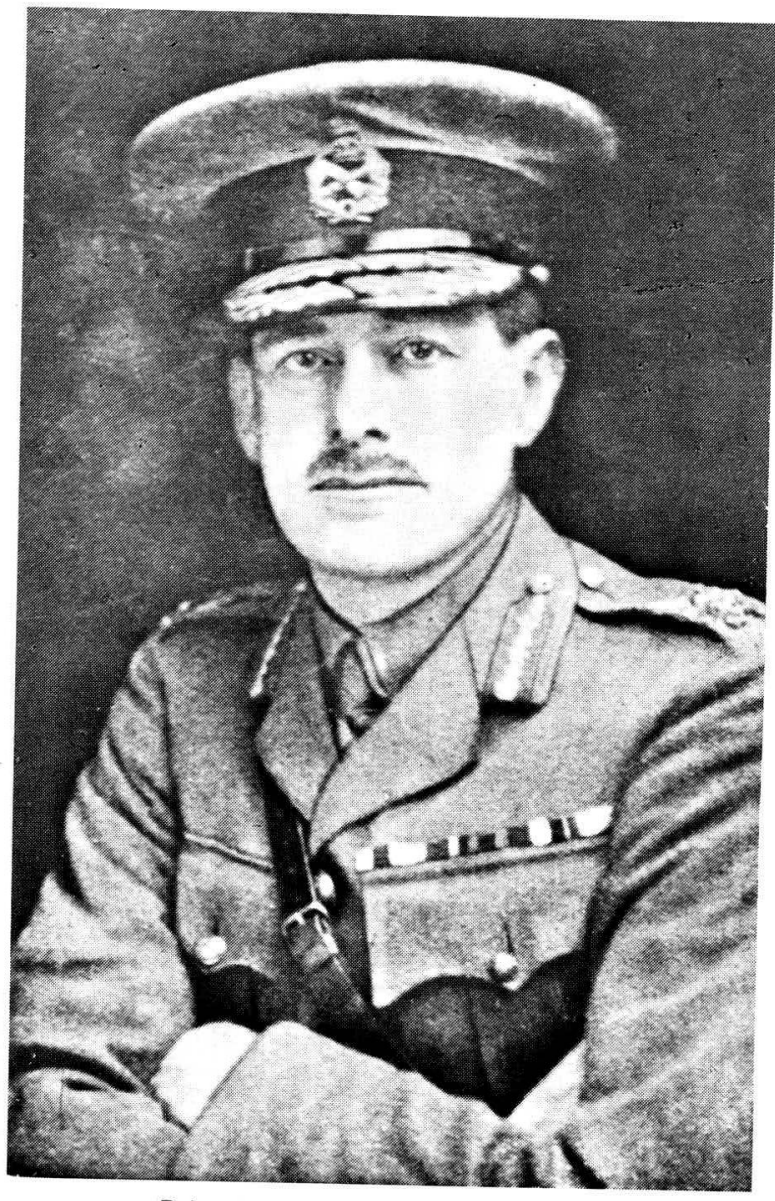

Brigadier General F.S. Dawson.

intense fighting by the remnants of the South African Brigade.

At one time the Germans galloped up two field guns in full view of Dawson's men. A Lewis gunner named Jeffries, a member of my old $C$ Company of the 1st Regiment, opened fire with his gun and sent men, horses and guns down in a struggling heap.

Intense shellfire from light and heavy artillery in the afternoon was followed by an attack from three fresh enemy battalions. By this time all ammunition was finished. Dawson and a few officers walked out in front and surrendered. They were taken prisoner with 100 men. Father Hill, who had been tending the wounded as usual, refused his freedom offered by the Germans and insisted on going with his men into captivity.

A staff officer of the 16th Division, taken prisoner, tells of a great tribute paid by the Kaiser to the 9th Division and especially to the South African battalions. Several German officers told him the last 


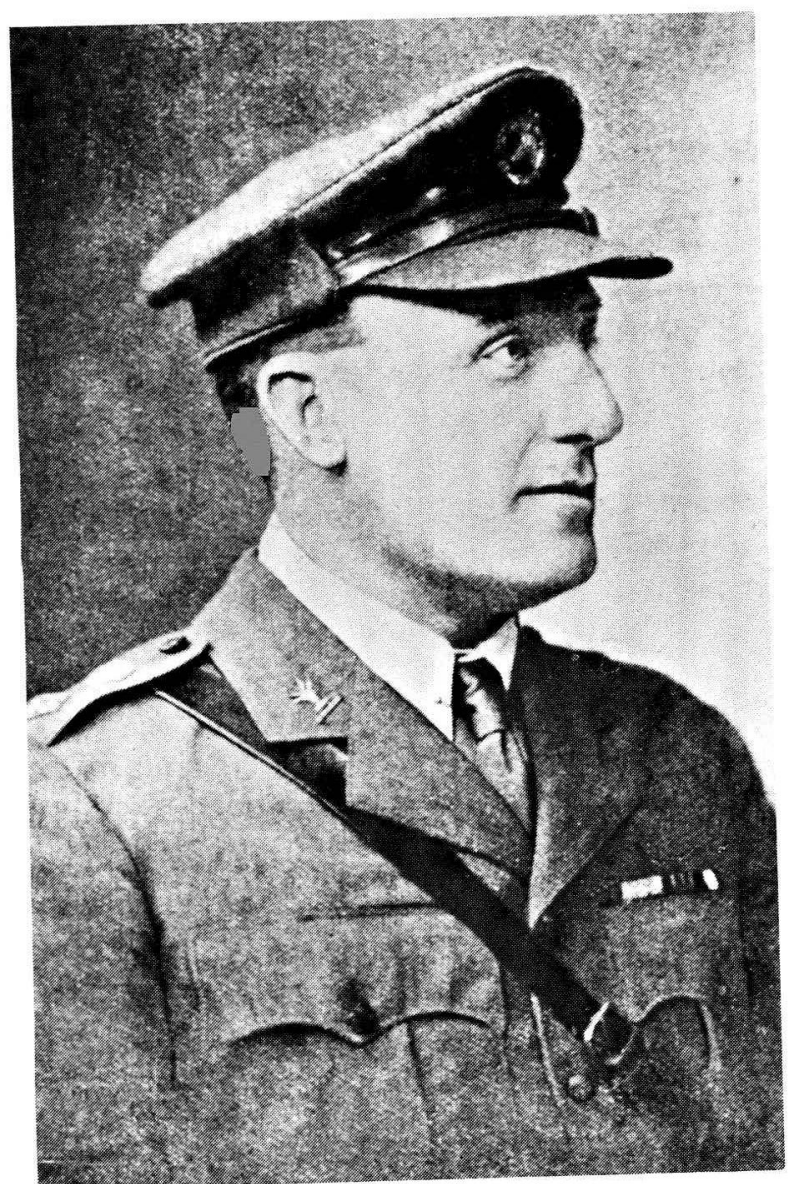

stand of the South African Brigade at Marrieres Wood was magnificent. At Le Cateau he says, " met two British officers who said while they were being marched back they were stopped by the Kaiser who said he was glad that his men had not always to meet men of the 9th Division or he would have no more troops with which to carry on his attack'.

On the morning of the 24th I reported back to the details and oddments left of our regiment then gathered at Bray. I saw Father Eustace Hill, MC, our wonderful one-armed padre, just before he left to join the Brigade that morning at Marrieres Wood. Here too I met my brother, Reg again and we were overjoyed to find each other alive.

At this time Captain Ward and Captain Burgess rejoined with the men in their companies who had lost touch with the regiment in the fighting retreat. We reformed here into three companies, each company of 100 men representing a regiment. We were greatly refreshed after a good sleep, washed and shaved, and above all, hot meals, the first for five days.
On the 26th we ${ }^{4}$ were ordered back to the line now being held at Dernacourt on the river. We marched back against the stream on the roads, choked with retiring troops and artillery. We held our heads up and marched proudly with a swinging step as if we were the Guards. I remember the retiring troops looking at us in amazement as if we were going the wrong way. We were singing as we marched, 'Mein Gott, mein Gott, what a bloody fine lot, the Kaiser he will say. Who are we? - we are - we are - the SA Infantry'.

On reaching Dernacourt we found we were needed to counter-attack a strong German position that night. The idea was to be a sudden bayonet attack in the dark. My brother officers said I was the man to lead it as I had recently been on an intensive bayonet fighting course. I was greatly relieved to hear later that the attack had been called off.

The following day, the 27th, we were ordered to positions in a ploughed field on a slight rise of ground. Here we were, in hastily dug shallow trenches overlooking an extensive part of the battle field in front. We watched with interest and admiration the 4th Australian Division hastily moved from reserve to stem the advancing enemy, going into action in artillery formation. We could see shells exploding amongst them, men falling and being left where they fell, but all going forward as if on parade. In the distance we could see great masses of our fighter planes diving down and strafing the enemy. Above us were RE.8's flying back and forth photographing or directing artillery. Three red triplanes, probably led by von Richtoven, dived down on these slow comparatively defenceless planes of ours. We would see a little spark in their petrol tank grow bigger and bigger and then down they would come. Five of our planes were shot down like this, one of them almost falling on us. Some of the pilots leapt out to their deaths or were dead already as they came down.

Shortly after this one of our Bristol fighter bombers was set on by the three triplanes and he put up a tremendous fight. His observer, Lieutenant A.W. Hammond, in the rear cockpit, blazed away trying to fight them off. The same small spark appeared and we thought, 'Here's another goner' as a mass of flames enveloped the pilot's cockpit. The pilot, Pilot Officer A.A. McLeod, climbed out on to the

4. The old South African Infantry Brigade had come to an end. The remnants, a composite battalion under Lieutenan Colonel Young, was withdrawn on the night of 27 March. 
left bottom wing of his biplane controlling the machine from the side of the fuselage by reaching in to the joy stick. By side slipping steeply he kept the flames to one side thus enabling his observer to continue firing until the plane had made three great circuits and reached the ground.

On landing the pilot, McLeod, started running away from the burning plane and his bombs that were liable to explode at any moment. Looking back, he saw his badly wounded observer rolling over and over away from the flames. He ran back although wounded himself and dragged his observer a short distance before the bombs exploded. They were both wounded again by the bombs and by enemy artillery and machine gun fire opened on them. By this time several of our men had reached them and at great risk carried them to safety in our trench. We attended to their wounds but could not safely get them away until dusk. Both were burnt and were in a bad way. Captain Ward and I cheered them as best we could until dark enough for our bearers to carry them back to a dressing station.

In trying to cheer McLeod I said, 'You will be in Blighty in a few days'. He said, 'That's just the trouble, I would like to have a crack at that so and so that brought me down'. The observer was too bad to talk; both smelt terribly of burnt flesh.

The following day, the 28th, we were relieved and the whole 9th Division was withdrawn from the line and sent North to join General Plumer's 2nd Army. We entrained on the 29th and eventually reached the Dickebusch area at the end of March. Here was great bustle as we reorganized and reformed our greatly depleted ranks. Every man that could be found in England was sent out and in a few days we had a Brigade 5 strength of 39 officers and 1473 other ranks.

We were all being re-equipped for battle order. Those who had been in the recent battle had lost everything. It was quite amazing how much could be claimed as lost, due to enemy action.

Amongst those who returned were many friends who had been wounded earlier and had now recovered. I met Major Jenkins, my old C Company Commander, who was wounded quite close to me in Delville Wood in July 1916 and was back again in September in time to be wounded again at the Butte de Warlencourt and was now back for more heavy fighting. Whilst refitting an RFC Major came looking for witnesses of Pilot McLeod's great feat. He said McLeod had been recommended for the
Distinguished Service Order but would very likely get the Victoria Cross if any officers could testify to what had occurred. My company commander, Captain Ward, MC and myself gave statements of what we had seen.

On about the 6th April the Brigade was inspected by General Plumer. We patched and mended our ripped puttees and clothing and did our best to give a really good turnout for affectionately known Daddy Plumer, Commander of the 2nd Army.

$\mathrm{He}$ told us that the battle down South had died down with the failure of the enemy to break through. The General Staff expected another heavy attack on this front. We were to be in reserve but in readiness to move at short notice.

Here at Dickebusch during the few days before the next battle claimed us, we puzzled over the enemy's success in the St Quentin battle.

Granted the fact that we were out-numbered by four enemy divisions to one of ours and that our brigade was 50\% understrength, and apart from clever new enemy tactics for breaking the trench system of defences, dense fog in the early morning of the first three days undoubtedly played a vital part in the battle.

Our infantry and carefully sited machine gunners, blinded by the fog and their gas helmets, were unable to see fifty yards ahead.

Under the blanket of fog and their devastating barrage, the enemy forward troops were soon cutting our wire and filtering unseen through selected gaps where our infantry had been overwhelmed by concentrated artillery and mortar fire.

Enemy troops suddenly appeared in flank and rear of our men, who then had to fight their way back and re-form on new lines of defence.

This process was repeated time and again by our men to avoid being surrounded and cut off.

Some isolated units held out stubbornly on their own though quite cut off into island pockets of resistance. Their tenacity and sacrifice gave opportunity for the general line to retire on strong points in the rear. By the sixth day the enemy's advance had come to a standstill and he was forced to break off the battle and look elsewhere for a further attempt to break the Allied line.

5. General Tanner, former Officer Commanding 2 SA Regiment, was given command of the reorganized Brigade. 


\section{THE BATTLE OF THE LYS}

\section{Messines Ridge. 10th April, 1918}

At 5.30 on the morning of the 9 th $^{\text {April }} 6$ we were awakened by the rumbling of very heavy gun fire coming from the front line some miles due East of us. We knew at once that this was the familiar opening barrage of the new great attack. We stood by all day awaiting developments.

The next morning the same rumbling gun fire, now much nearer, woke us and we knew we would be called in again. Soon orders arrived that we were to stand by ready to move at half-an-hour's notice. ${ }^{7}$ A hurried breakfast was served before we moved off on a four-hour march to our deploying positions. We passed through the villages of Voormezeele, Wytschoete, Wulverghem and Neuve Eglise. Just south of Neuve Eglise we halted and awaited orders.

The villages we had passed through had so far escaped the ravages of war. Now with the sudden attack and bombardment, farms and villages were wrecked and the unfortunate civilians fleeing in terror with what few belongings they could carry or push in a wheel barrow, or carts. Marching through Neuve Eglise we had to step over the bodies of ambulance men hit by shell fire. There was a break for a meal and to dump all unnecessary kit. We prepared to go into action with the lightest equipment possible.

A conference of all officers was called for by General Tanner who had recently returned to us from the Royal Scots to command our brigade. He had previously commanded the 2 nd Regiment and his return was welcomed by all.

We were assembled in a Nissen hut for our briefing. General Tanner told us that as the result of the attack that morning the position was very serious. The line had been broken and there was a mile gap between two British divisions. Our orders were to counter attack and re-take the ground lost and to hold it at all costs. Unfortunately there were no maps to be had. There would be one battery of New Zealand field guns to support us. Our objective was the Messines Wytschoete road on the crest of the Messines Ridge. The 1st Regiment would be on the right, the 2 nd on the left with the 4th Regiment in support. He finally asked if there were any questions. I jumped up and said as commander of the platoon on the extreme right, were there any landmarks that would serve as a guide. He gave me what he said were only very rough directions. We all piled out of the hut looking pretty glum at the idea of tackling a forlorn hope and got busy. My brother, Reg, came looking for me and we moved aside and had a little talk. We both knew our chances of surviving this attack were very slim and we consoled each other as best we could. I remember saying, 'What hard luck on our parents to lose both of us on one day'. We made the best of it, however, and went off to our different tasks. Talking to some of our officers, I said, "I hope this time / shall get either a really good smack or not survive.' How can one explain the psychological state of a young man who has had two years of constant strain and been face to face with death so often? Probably the hardest strain is in being a young officer as fearful as any, who has not only to pretend to be unafraid, but has to be cool and calm in the heaviest shell fire and set an example that will steady his men.

Being second in command of A Company, I was called to our temporary orderly room by Captain Ward to help him deal with a very distressing and ignominious incident. A man in civil life, an exponent of physical culture, had been a Physical Training Instructor at our base camp in England. He had consistently evaded the many replacement drafts of men called for in the past. In fact he had lived the good life in uniform, taking advantage of the fighting man in the field. Now with the urgent call for men to replace our heavy losses there were no excuses taken from anyone and he was sent out with the last draft. He was now pleading with Captain Ward to be left out of this attack. To see a man completely broken down, begging for his life was most upsetting. We, who were not too happy ourselves, had to refuse and tell him that we were all in the same boat and he would be taking no more

6. By 6 April 1918 the German thrust towards Amiens had failed, and for the moment the gate of the Somme was closed. Although brought to a standstill Ludendorff could not permit the battle to decline into a stalemate, and lose the initiative. Instead he planned a subsidiary operation to cast diversion in order to prepare the way for the accomplishment of his main task in the south. Hence he decided to attack the British on some part of the front where they were notoriously weak thus compelling them to use their reserves for its defence. As the German High Command was aware that the area on both sides of the Lys between the La Bursié Canal and Wytschoete Ridge had been thinned to supply the operations in the south, and that it was weakly held - mainly by troops exhausted in the Somme battle - it was chosen as the battle-ground. On 9 April he struck between the Lys and La Bassíe.

7. The South Africans were placed at the disposal of the 19th Division, which, along with the 25th and 9th Divisions, was holding the Messines Ridge and the line just north of the Lys. 
risks than any one of us. Finally, he was sternly told, 'You are a sergeant - pull yourself together and fall in with your platoon'. We moved to our attacking positions soon after and within the hour both he and Captain Ward were dead.

We marched to our jumping-off spot in artillery formation partly screened by a light mist and fog. Before extending into attacking order the boys were singing, though well aware of being sacrifice troops with a grim future before them. The song they sang was, 'Good-byee, don't sighee, wipe the tear, baby dear, from your eyee, - goodbyee'. We passed over other front line troops dug into little slit trenches; they looked up and seemed astonished to see us moving over them into the open. When about 800 to 1000 yards from the crest of the ridge and our objective, Captain Ward blew his whistle and gave the signal for us in conformity with the adjoining companies to extend. We formed into three lines, or waves, of attack. Captain Ward now came up to me and said, 'You know, Lawrence, this is not fair, you and I have been through it time and again - we can't go on like this and get away with it'. I said, "I know, skipper, its bad luck', and to break the tension suggested I should take the front wave and guide our right flank. He agreed and took charge of the second wave with a junior officer, Second Lieutenant Hopgood, leaving two other junior officers to the third wave. We shook hands and all moved forward at his signal. Going forward at a sharp pace, something prompted me to do a thing I had never thought of doing before. I quickly stooped down and picked up an abandoned rifle and bayonet, slung it over my shoulder and carried on. This very likely saved my life for officers were always picked off first. Wearing, as we did then, a worsted star on a private's tunic I was not conspicuous when carrying a rifle.

Machine guns and rifle fire opened up on us at once. They had been holding their fire until now. The chattering machine guns were sweeping first one way and then back. Men were dropping here and there. As the sweep of the machine guns came on to me the bullets gave a clap like a whiplash in my face and then moved by, coming back and forth each time with that sharp crack. I moved as fast as I could as more and more men were dropping. I went on until looking around I saw there were only three of us left in the front wave. I put my hand high up in signal for halt and dived for a shell hole. The two men on my right and a few yards behind unfortunately tried to come up in line with me. As I looked from the shelter of my shell hole one fell dead, the other ran up and stooped over the first to help, when he too fell dead on top of his pal. Just then three men of the second wave came up and plunged into a shell hole to the right and forward of me.

I remember I had a small Scotch thistle growing on the edge of my shell hole and I tried to hide as much as I could behind it. I opened fire at once with my rifle at the Germans now only 75 yards distant, some of them standing up and firing. I accounted for five certainties very quickly and continued picking off more in the trench as I was looking down its full length. I then threw clods at the sergeant and two men in their shell hole on my right and told them to open fire. This they did with good effect. At this stage Second Lieutenant Clarke and a man from the third wave came up and jumped into cover near me. He told me Captain Ward and Second Lieutenant Hopgood had been killed and he thought all the other officers in our regiment were either killed or wounded. This left me in charge. We had now quietened down the fire from the trench in front of us. I decided that as we had not reached our objective on top of the rise had to get to the centre and organise a further attack.

I told Clarke and the others to open up with rapid fire to cover me. Leaving my rifle I ran across the enemy front to our centre. I jumped from shell hole to shell hole and reached a collection of brokendown walls where I found a young 4th Regiment officer with about twenty men. I sugggested we make a dash forward to gain our objective. I was about to look over the wall we were behind when someone stopped me and said a man had just been shot through the head looking over. After talking things over a short while, I said, 'I will lead if your men will follow me'. They agreed. I blew my whistle, drew my pistol and set off into the open skirting a large shell hole on my right. I had not got more than 40 yards when something hit me like a sledge hammer in my left thigh. It seemed red hot and spun me round completely before I fell. I lay perfectly still waiting, as I thought, for the second bullet. There was another big shell hole right alongside me so I gave a quick lurch and rolled down out of sight and into the green water at the bottom. I pulled myself out and on to the slope at the side above the water. Here I knew I was fairly safe for the moment, at any rate, from rifle fire. By this time the light was fading, it being about seven o'clock. I must have fallen asleep after a while for I woke to find a young 
corporal named Reunert bending over me in the dark. He bandaged up my leg very effectively and stopped the heavy bleeding. I had been slipping down the side of the shell hole into the water between dozing so he stuck a bayonet into the ground below me. This kept me out of the water. $\mathrm{He}$ told me all the stretcher bearers were either dead or wounded but he would try to get help for me later. He covered me up with my rain coat and left. At midnight heavy enemy shelling started and was answered by our rifle and machine gun fire. Fortunately the shells were falling just behind me for I was now in no man's land and close to the enemy. Verey lights of all colours shot up illuminating everything round about. I thought now the Bosch is surely coming over. I drew my revolver and wondered what to do ... to fight or surrender probably death either way. To my relief the firing from both sides died down and nothing happened. Just before dawn the corporal and three men came to help me. I tried to stand but could not, probably from loss of blood. The bullet at such short range had turned on the thigh bone and gone through sideways making a fist-sized hole where it came out. These good chaps put me on my raincoat and taking the four corners carried, or dragged, me over the shell holes and broken wire for what must have been quite 500 yards down the slope to a small dugout used as a first aid post. As they were nearing half-way down the slope an enemy plane saw us and dived down quite close, but to our relief he was a decent fellow and swooped away without firing. Corporal Reunert and his men left me to return to their duty in the line and I often wonder what happened to them and if they survived the war. The poor fellows in the shelter or dugout were in a bad way, most of them.

The medical corps man in-charge gave us tea and quite soon two men with a stretcher on wheels arrived and took me off at a trot. Coming to a bridge they looked at the time, left me on the stretcher and dived below as a salvo of shells arrived. Splinters flew all around but my luck was in. The firing stopped abruptly, up came the bearers and off we went at full speed before the next salvo dropped. This little act was repeated at the next known hot spot and afterwards we were soon getting somewhere. Another stop at a dressing station where a doctor hastily examined my leg, took a sniff and sent them on. Again another dressing station and more sniffs and then finally to the casualty clearing station.

Here in a marquee tent I was undressed and put into a lovely bed. I remember the orderly apologising for cutting off my tailor-made riding breeches.
Soon I was taken into the operating theatre sited in a make-shift little room in which the doctors waded in blood in thigh gum boots. I looked apprehensively at a great pile of legs and arms in the corner. When the very sweet sister came to give me chloroform I begged her not to let them take my leg off as seemed very likely in their haste to deal with gangrene cases.

With the front line nearby in danger of pulling back at any moment, casualties had to be summarily treated. She was very soothing and hoped they would just clear the gangrenous tissues in the path of the bullet. This was done and I next awoke in a hospital train that landed me in a Rouen hospital.

Looking back in sadness and with regret at our many casualties, one is consoled by the thought of the great urgency of our counter-attack in the critical situation that had developed as the result of the enemy break-through. The 9th Division had again been called on to fill the breach and our brigade, a component of it, had played the major part in the assault. We had succeeded in our objective in filling the mile gap between two divisions lost to the enemy and held it for thirty hours against heavy attacks until relieved. The heaviest casualties and fighting had fallen to the 1st Regiment on the right. With comparatively few casualties the 2nd Regiment had gained all their objectives and taken many prisoners. The 1st Regiment lost 3 officers killed and 9 wounded with a proportionate number of other ranks in the assault.

An unusual honour to so small a unit was paid by Mr Winston Churchill in his book The World Crisis - I quote:-

'On the Northern flank of the offensive lay the 9th Scottish division whom we left unshakeable at Nurlu on the morning of March 21. After fighting with the utmost distinction and success in that great battle and losing over 5000 officers and men, it had been hastily filled with drafts and brought to rest and recuperate in what was believed to be a quiet station.

The whole front to the southward having been beaten in, its right flank was turned back and the resurrected South African brigade at four in the afternoon of the 10th drove the Germans from the Messines crest. All efforts to oust this division from the position into which it had clawed itself, failed. Thus the buttresses stood immovable although the wall between them was completely battered in. 
Upon this fact the safety of the whole front and the final result of the battle unquestionably depended'.

\section{Hospital and Homeward Bound}

I was kept in Rouen hospital for some days before being put aboard a hospital ship. After operating, my thigh wound, a gash $10 \times 4 \times 2$ inches, had been packed with seemingly endles lengths of cotton gauze to check loss of blood en route to the base hospital. This stained fast-sticking gauze was pulled out yard by yard by a heartless doctor, or so I thought, who refused my appeal for a sedative. In my desperation I damned him for his callousness. He threatened to put me under arrest and I told him to get on with it. Amidst sympathetic cheers from the rest of the ward he glared at me and walked out.

Soon afterwards all of us who were fit for the voyage were taken to the docks and laid out on stretchers awaiting our loading. A young Padre came over to me and asked why I was so pale - a queer question, I thought, and offered to get me a meal. He came back with a good plate of food and noticing for the first time my worsted star of rank apologised for bringing me other ranks' food. I thought this distinction even more queer and said so.

After a quiet crossing we landed at Dover and soon reached the London terminus. From here I was sent by ambulance to the Prince of Wales Hospital in Baker Street. We were off-loaded at the entrance and whilst waiting for our allocation to our respective wards, a small crowd seemed to think we were part of London's daily show. However, they were all very kindly and sympathetic with their remarks.

This was a very well run hospital mostly for officers as far as I could see. Who should be in a ward close by but Pilot Officer Alan A. McLeod, VC, the gallant airman whom our men had rescued from their burning plane downed in front of our trench and evacuated after dark with his badly wounded observer. He was now in a very serious condition and not expected to live. His parents had been sent for from Canada and were with him at the time. We heard later that he recovered and was invalided out of the air force and returned to his home in Canada only to eventually die of his wounds. Lieutenant Hammond, his observer, was awarded the Military Cross.

This 'dog fight' is recounted in Famous Air Battles by John Frayne and in VC's of World War I.
I was very well looked after in the Prince of Wales Hospital though they nearly put me out completely with what must have been at least my fourth injection of anti-tetanus serum. I reacted very badly as I had always done on previous occasions. A dear old Sister was terribly shocked when washing me, to find after a month's very active fighting service that this was my first real bath. We had slept when and where we could, sometimes in old enemy dugouts infested with vermin. I had to have a thorough and embarrassing overhaul.

I was very relieved about this time to get the good news of my brother Reg being wounded and out of the line for the time being. He had had a terrific bang on his tin hat by a large shell fragment that just penetrated his hat and knocked him senseless with a sizeable flesh wound, and no more.

After a month here I was taken on a long trip through London by ambulance to the South African Military Hospital at Richmond. The young officer in charge was getting off heavily with the pretty W.A.C. ambulance driver and in consequence she was driving very fast and recklessly. Half way they looked back to see how their patient was getting on. On seeing me hanging on grimly and rather pale, they stopped and apologised and from then on sobered down and drove at a slower pace until reaching our destination.

Richmond Hospital was home from home and in the officer's ward were many of our brigade whom I knew. In charge was one of the sweetest Sisters ever and loved by us all - Sister Campbell, who looked after us all equally well, was won by a very fine man - Lieutenant Arnold, one of those badly wounded when their cook's spiralling trickle of smoke was spotted from Fritz's balloon and their dugout wiped out by a direct hit. On that occasion my friend, Captain Bryant was killed together with Second Lieutenants Dickerson and Mandy, and Pope-Hennessy wounded.

Pat Arnold and Sister Campbell were married a year later when he had recovered and been equipped with a 'tin leg'. He, poor fellow, was riddled with twenty-two separate wounds and was having constant operations.

After an operation to close up the open gash in my thigh, I was soon on the mend and remained very happily at Richmond until early September. 
I had a very nice fellow in bed next to me, a Second Lieutenant Stephenson of our Scottish. In the heavy fighting in the St Quentin battle, or March retreat, Stephenson was with his regiment's rear guard fighting a holding withdrawal in close touch with the enemy, when a bullet struck the watch on his left arm, shattered his wrist and drove the contents of the watch into his stomach, slicing it open. $\mathrm{He}$ had to run down under fire from the enemy close behind him, holding his entrails with his other hand to keep them from falling out. He just made it to a dressing station. Now he was well on the mend and the cheeriest chap in the ward and a great 'hit' with the girls on the river. He was a good-looking strapping lad with the added charm of all the finery of a Highland kilt. He over-played his luck punting one afternoon on the Thames. His one arm in plaster and using the punting pole vigorously with the other, he found himself dangling at the end of the pole with the punt away beyond the reach of his feet and, of course, flopped into the water. His luck then held, however, and with much feminine laughter ready hands pulled him out and one took him home, washed and dried his uniform whilst he sat in absent husband's clothes. We others still hors de combat could only sigh for similar fortune!

About this time as the result of our regiment's rear guard action at Nurlu on the 23rd March my name appeared in The Times with others mentioned in the despatches of Field Marshall Sir Douglas Haig. So all these good chaps came over to my bed to give me a handshake. Also resulting from action in the March Retreat Captain Ward, MC, who fell at Messines Ridge, was gazetted with the award of a bar to his Military Cross.

The hospital doctor's little nine year old daughter used to accompany him to see 'the man with a screw in his leg' and 'the man with a watch in his tummy'. They were still taking bits of watch springs from Steve's insides.

Second Lieutenants Uys, Mackensie, Stokes, Captain Tobias and many others of our brigade were very cheery friends, so that as September approached I was regretfully thinking of having to leave our happy, homely ward.

A Medical Board decided I was to be invalided out of the army and sent home on the Galway Castle. My brother officers remonstrted and said 'You can't go back with a lame leg like that, you should apply to a board for more medical and convalescent treatment'. As a result I was boarded by three Colonels at the War Office, one of them being Colonel
Sir Frederick Treeves, famous for his appendix operation on King Edward VII. This board cancelled the former board decision and ordered further treatment and my return home by hospital ship. At very short notice I was given a through ticket by hospital train across France to Marseilles, by sea to Alexandria, overland to Port Suez, and down the Red Sea on the hospital ship Dongola Castle to Durban. In this way I escaped the fate of the Galway Castle torpedoed with serious loss of life two days out of Southampton in mid-September.

We had a most uncomfortable voyage down the Red Sea, sailing with a following wind, the heat was truly terrific. A number of Labour Corps Natives went mad and threw themselves overboard and were lost. On arrival in Durban harbour, we were flying the yellow flag, for the Spanish 'flu was raging in the Cape and other parts of the Union. Except for two spinal cases all of us, about eighty disabled men, were landed on Salisbury Island where we lived in tents for ten days. The Island then, was to us quite a tropical paradise, green and very well wooded and with birds of every kind. At night I would lie awake listening to the noises of thousands of tropical insects and watching the brilliant fire flies. After hot shipboard life this was truly a wonderful taste of tropical Africa. With books, games, fruit and many comforts, sent to us by the kind ladies of Durban, we all thoroughly enjoyed our stay despite the longing of everyone to reach home and journey's end.

A few hundred discharged soldiers had dribbled back in batches from the East African Campaign and they were to swell our numbers and join in the great civic welcome that had long been planned.

We had picked up four or five disabled officers at Alexandria, all senior to myself, who had travelled with us by train overland along the Suez Canal to Port Suez. One night we were told there was a great welcome awaiting us the next day. We were to leave the Island for new quarters on the mainland, after being entertained to a luncheon in the Town Hall by the Mayor and public of Durban.

The senior officer of our six, Captain Thompson of the air force, said to me 'You are the only officer of the South African Brigade and will have to reply to the Mayor's speech of welcome'. This rather shook me and somewhat disturbed my usual good night's sleep, working on a suitable reply. I was determined, however, to make a success of it and uphold the good name of the Brigade. 
At midday the next day boats arrived to take us over to the mainland. Here, taxi drivers were waiting to give us free lifts to the Town Hall. As we stepped out at the main entrance, the chief of proceedings was there to welcome us and immediately asked who was going to reply to the Mayor's speech of welcome. My companions grabbed me with joy and said 'Here he is!' I was led off 'like a lamb to the slaughter' and seated on the right of the Mayor with a red-tabbed staff Colonel on my right at the main table.

All ranks were piped into the hall by a Highland piper in full regalia. About 200 sat down to luncheon. The hall was crowded with well-wishers and parents and relatives of the ex-soldiers. In due course the Mayor rose and certainly gave his speech 'stick' and seemed to speak endlesslv

With victory in the air on the Western Front our men came in for a great deal of praise for the part the brigade had played in the many great battles that were now culminating in final victory. Meanwhile I took a few good gulps of claret cup.

When the Mayor, amidst great applause, finally sat down, my turn came, to say my piece as shortly as possible, on behalf of our returning men, the brigade, and our fallen comrades.

After luncheon we were taken on a free trip around Durban and its suburbs by the patriotic taxi drivers before being deposited in our new quarters in the Berea area. After a short stay I entrained for the final journey home. It was a joyous and exhilarating feeling as the train wound through the beautiful valley of a Thousand Hills towards Pietęrmaritzburg and from there climbing up and around countless bends to the top of Van Reenen's Pass. Reaching Harrismith and Bloemfontein, we headed south and were then truly homeward bound. Tulbagh Road Station was reached at last and there my father joyously welcomed me. We drove the short distance home to my overstrained but very happy mother.
How good it was to be back, to home, parents, and many friends. I was now a civilian again after all these long years - years that seemed so long at that age and under those conditions. My parents had suffered many anxious moments during their sons' absence overseas. Their joy was complete when my younger brother, Reg, also wounded at Messines Ridge, returned home six months later. He went back to University and finished his interrupted course there.

To finish my story, the Mayor of our village gave me a great welcome at a public gathering and presented me with an address from the people of Tulbagh and as the news came through on the morning of the 11th November, I had the privilege of ringing the Law Courts bell loud and long, proclaiming both Armistice and victory and hopefully ringing in the ideals we had striven for; the honour of our country and lasting peace.

I see across the shrapnel-seeded meadows The Jagged rubble-heap of La boiselle Blood-guilty Fricourt brooding in the shadows And Thiepval's chateau empty as a shell. Down Alberts riven streets the moon is leering, The Hanging Virgin takes its bitter ray; And all the road from Hamel I am hearing The silver range of bugles over Bray.

Once more within the sky's deep sapphire hollow I sight a swimming Taube, a fairy thing; I watch the angry shell flame flash and follow In feather puffs that flick a tilted wing; And then it fades, with shrapnel mirrors flashing

The flashes bloom to blossoms lily gold The batteries are rancorously crashing, And life is just as full as it can hold.

- Robert Service 